\title{
Confirmation of the Species Prevotella intermedia and Prevotella nigrescens
}

\author{
ELLEN V. G. FRANDSEN, ${ }^{*}$ KNUD POULSEN, ${ }^{2}$ AND MOGENS KILIAN ${ }^{2}$ \\ Department of Oral Biology, Royal Dental College, ${ }^{1}$ and Department of Medical Microbiology and Immunology, ${ }^{2}$ \\ Faculty of Health Sciences, University of Aarhus, DK-8000 Aarhus C, Denmark
}

\begin{abstract}
The elevation of the two genotypes of Prevotella intermedia to species rank as $P$. intermedia and Prevotella nigrescens has increased the need for reliable differentiation between the two taxa. In this study, 53 strains, including strains whose species affiliations were known as well as fresh dental plaque isolates, were subjected to a multilocus enzyme electrophoretic analysis, DNA analyses in which we used whole genomic DNA, rRNA sequences, and an oligonucleotide specific for the former $P$. intermedia genotype II (P. nigrescens) as probes, and a sodium dodecyl sulfate-polyacrylamide gel electrophoresis analysis of soluble cellular proteins. All of these tests consistently separated the strains into the same two distinct groups corresponding to $\boldsymbol{P}$. intermedia and $P$. nigrescens, confirming that the two species constitute two distinct populations of bacteria. Each of the tests used independently provided reliable identification to the species level. A previously reported heterogeneity in the pattern of human immunoglobulin A1 (IgA1) degradation was not confirmed. No differences between species were observed. All of the strains induced total degradation of IgA1 within $48 \mathrm{~h}$, a property that may be a virulence factor in periodontal disease development. The enzymes responsible for IgA1 degradation were not inactivated by the physiological proteinase inhibitors $\alpha_{2}$-macroglobulin and $\alpha_{1}$-proteinase inhibitor.
\end{abstract}

Prevotella intermedia (formerly Bacteroides intermedius) is a gram-negative, obligately anaerobic rod that is often isolated from subgingival plaque of humans with periodontal disease and from other oral and nonoral infections (for reviews see references 10,18 , and 26 ). The two previously recognized genotypes of $P$. intermedia (12) were recently elevated to species rank as $P$. intermedia, corresponding to genotype I, and Prevotella nigrescens, corresponding to genotype II (24). However, the suggested tests that distinguish the two species (24) have proved to be difficult to reproduce in other laboratories. The suggested association between $P$. intermedia (genotype I) and periodontal disease $(7,9,18)$ has strengthened the need for reliable tests to differentiate the two species.

In addition to analysis of levels of homology between wholecell DNAs (24), serotyping with monoclonal antibodies $(8,9)$ and hybridization to an oligonucleotide based on $16 \mathrm{~S}$ rRNA sequences from the former $P$. intermedia genotype II (3) have been reported to be methods that can be used to distinguish the two genotypes of the former species $P$. intermedia. In addition, sodium dodecyl sulfate (SDS)-polyacrylamide gel electrophoresis (PAGE) of soluble cellular proteins has been used to differentiate the two taxa $(7,12)$.

In this study we used several methods, including multilocus enzyme electrophoresis, restriction fragment length polymorphism (RFLP) analyses in which we used whole genomic DNA as well as rRNA-derived sequences as probes for hybridization, and SDS-PAGE of soluble cellular proteins to evaluate the value of these methods for discriminating between $P$. intermedia and $P$. nigrescens. We performed tests with 53 strains, including the type strains, other strains assigned to one of the species according to the recent taxonomic revision (24), and fresh dental plaque isolates. The resulting data were combined with the results of an examination of the ability of each strain to degrade human immunoglobulin A1 (IgA1), a potential virulence factor in periodontal disease development, in order to determine whether the previously observed diverse pattern of IgA1 degradation (14) is species related.

\footnotetext{
* Corresponding author. Phone: 458942 17 39. Fax: 4586196128 .
}

\section{MATERIALS AND METHODS}

Bacterial strains. Of the 53 strains included in this study, strains CCUG 24041 (= ATCC 25611 ${ }^{\mathrm{T}}$ ) ( $\mathrm{T}=$ type strain), MH3, MH6, MH7, MH14, MH15, MH16, MH18, OMZ248, and OMZ324 were assigned to $P$. intermedia and strains CCUG $9560^{\mathrm{T}}\left(=\right.$ NCTC $9336^{\mathrm{T}}=$ ATCC $\left.33563^{\mathrm{T}}\right)$, BEF3 $\left(=\right.$ NCTC $\left.9336^{\mathrm{T}}\right)$, NCTC 9338, MH11, MH20, OMZ251, OMZ265, OMZ328, OMZ310 (= T588) and HG65 (= T588) were assigned to $P$. nigrescens according to the recently published taxonomic revision of the species $(24)$. The remaining $33 P$. intermedia strains had not been reclassified after revision of the species. These strains included strains HG189, BN116, OMZ256, OMZ276, OMZ326, UJB13-c $\mathrm{AB} 13 \mathrm{a}-\mathrm{f}$, and P11a-k and 25 strains freshly isolated from subgingival plaque on nonselective agar plates in our laboratory. The strains were received from the following sources: strains CCUG $24041^{\mathrm{T}}$ and CCUG $9560^{\mathrm{T}}$, Culture Collection of the University of Göteborg, Göteborg, Sweden; strain NCTC 9338, National Collection of Type Cultures, London, United Kingdom; strains MH3, MH6, MH7, MH11, MH14, MH15, MH16, MH18, MH20, and BN116, H. Shah, Eastman Dental Hospital, University of London, London, United Kingdom; strains OMZ248, OMZ251, OMZ256, OMZ265, OMZ276, OMZ310, OMZ324, OMZ326, and OMZ328, R. Gmür, University of Zürich, Zürich, Switzerland strains HG65 and HG189, T. J. M. van Steenbergen, Vrije Universiteit, Amsterdam, The Netherlands; strain BEF3, J. Carlsson, University of Umeå, Umeå, Sweden; strains UJB13-c, AB13a-f, and P11a-k, G. Sundqvist, University of Ume ̊, Ume ̊̊, Sweden; and strains MHS1-20, BK27, BK28, BK29, BK30, BK31, BK32, BK33, BK35, BK36, BK37, BK38, BK22, BK19, BK20, BK21, BK23, BK24, BK25, BK26, BK34, MHS1-18, MMJ1-22, MMJ1-23, and MMJ1-24, our laboratory. The 25 freshly isolated strains were assigned to the species $P$. intermedia as previously defined on the basis of the results obtained in the following tests: Gram staining; formation of black-pigmented colonies on blood-containing media; selective growth in an anaerobic atmosphere; production of indole (15) trypsin (17), $\beta$-galactosidase, $\beta$-glucosidase, $\beta$-glucosaminidase, $\alpha$-glucosidase, and $\alpha$-fucosidase $(13,16)$; and fluorescence under UV light $(25)$. The strains were grown on plaque agar plates or in liquid plaque medium for all analyses (11).

Multilocus enzyme electrophoretic analysis. A $15-\mathrm{ml}$ portion of a dense starter culture was used to inoculate $150 \mathrm{ml}$ of medium, which was incubated anaerobically for $48 \mathrm{~h}$. Bacteria were harvested by centrifugation, and the pellet was suspended in $2 \mathrm{ml}$ of $50 \mathrm{mM}$ Tris-HCl-5 mM EDTA ( $\mathrm{pH} 7.5$ ), frozen at $-20^{\circ} \mathrm{C}$ for $2 \mathrm{~h}$, thawed on ice, and sonicated intermittently for $10 \mathrm{~min}$ with a model B-12 Sonifier (Branson Sonic Power Co., Danbury, Conn.) equipped with a small tip at setting $4(40$ to $50 \mathrm{~W})$. The sonicate was frozen again at $-20^{\circ} \mathrm{C}$ for $2 \mathrm{~h}$, thawed on ice, and centrifuged. The supernatant was stored at $-70^{\circ} \mathrm{C}$ until it was used. Multilocus enzyme electrophoresis was performed on horizontal starch geis as described previously $(20,23)$. Electromorphs (mobility variants) were determined for the following metabolic enzymes (the buffer systems used [25] are indicated in parentheses): glutamate dehydrogenase (buffer system A), malate dehydrogenase (buffer system A), adenylate kinase (buffer system A), indophenol oxidase (buffer system A), nucleoside phosphorylase (buffer system A), glyceraldehyde-3-phosphate dehydrogenase (buffer system G), carbamate kinase (buffer system I), phosphoglucomutase (buffer system I), phosphoglucose 
TABLE 1. Numbers of electrophoretic alleles and levels of genetic diversity per enzyme locus for 51 strains of $P$. intermedia and $P$. nigrescens

\begin{tabular}{|c|c|c|c|c|c|c|c|c|}
\hline \multirow{2}{*}{$\begin{array}{l}\text { Enzyme } \\
\text { locus }^{a}\end{array}$} & \multicolumn{7}{|c|}{ Frequency of the following alleles: } & \multirow{2}{*}{$\begin{array}{l}\text { Genetic } \\
\text { diversity }\end{array}$} \\
\hline & 1 & 2 & 3 & 4 & 5 & 6 & 7 & \\
\hline $\mathrm{ADK}$ & 0.32 & 0.11 & 0.47 & 0.02 & 0.09 & & & 0.65 \\
\hline GDH & 0.35 & 0.06 & 0.59 & & & & & 0.52 \\
\hline MDH & 0.52 & 0.23 & 0.02 & 0.04 & 0.06 & 0.08 & 0.04 & 0.66 \\
\hline NSP & 0.46 & 0.46 & 0.04 & 0.04 & & & & 0.56 \\
\hline IPO & 0.59 & 0.18 & 0.02 & 0.09 & 0.09 & 0.02 & & 0.59 \\
\hline GPI & 0.38 & 0.04 & 0.54 & 0.04 & & & & 0.55 \\
\hline PGI & 0.28 & 0.06 & 0.54 & 0.06 & 0.02 & 0.02 & 0.02 & 0.61 \\
\hline $\mathrm{CDK}$ & 0.32 & 0.68 & & & & & & 0.42 \\
\hline PGM & 0.69 & 0.05 & 0.24 & 0.02 & & & & 0.50 \\
\hline GP1 & 0.71 & 0.25 & 0.04 & & & & & 0.42 \\
\hline GP2 & 0.59 & 0.39 & 0.02 & & & & & 0.49 \\
\hline GP3 & 0.59 & 0.39 & & & & & & 0.49 \\
\hline LGG & 0.75 & 0.25 & & & & & & 0.36 \\
\hline PLP & 0.51 & 0.47 & 0.02 & & & & & 0.51 \\
\hline
\end{tabular}

“ Abbreviations: ADK, adenylate kinase; GDH, glutamate dehydrogenase; MDH, malate dehydrogenase; NSP, nucleoside phosphorylase; IPO, indophenol oxidase; GPI, glyceraldehyde-3-phosphate dehydrogenase; PGI, phosphoglucose isomerase; CDK, carbamate kinase; PGM, phosphoglucomutase; GP1, glycyl-DL-phenylalanine peptidase; GP2, glycyl-phenylalanine peptidase; GP3, glycyl-leucyl peptidase; LGG, leucyl-glycyl-glycyl peptidase; PLP, phenylalanine-leucyl peptidase

${ }^{b}$ The mean genetic diversity for all enzyme loci was 0.52 .

isomerase (buffer system I), glycyl-DL-phenylalanine peptidase (buffer system $\mathrm{H}$ ), glycyl-phenylalanine peptidase (buffer system $\mathrm{H}$ ), glycyl-leucyl peptidase (buffer system $\mathrm{H}$ ), phenylalanine-leucyl peptidase (buffer system $\mathrm{H}$ ), and leucyl-glycylglycyl peptidase (buffer system $\mathrm{H}$ ). All substrates were obtained from Sigma Chemical Co., St. Louis, Mo.

The level of genetic diversity $(h)$ at an enzyme locus among strains (i.e., the probability that two randomly chosen strains have different alleles of the locus) was calculated from allele frequencies as follows: $h=1-\Sigma x_{i}^{2}[(n /(n-1)]$, where $x_{i}$ is the frequency of the $i$ th allele of the locus and $n$ is the number of strains. The genetic distance between electrophoretic types (ETs) was expressed as the proportion of enzymes for which dissimilar electrophoretic mobilities were observed. A dendrogram was constructed from the data obtained from a computerized cluster analysis performed by the average-linkage method by using a matrix of pairwise genetic distances between ETs and the program ETCLUS, which was kindly provided by T. S. Whittam, Department of Biology, Institute of Molecular Evolutionary Genetics, Pennsylvania State University, University Park. The absence of enzyme activity was treated as missing data.

Southern blot analyses. Total cellular DNA was prepared from a $10-\mathrm{ml} 24$ - to 48-h liquid culture as described previously (21), except that lysozyme was omitted from the preparation. The quality and concentration of DNA were determined by agarose gel electrophoresis.

Approximately $2 \mu \mathrm{g}$ of total cellular DNA was subjected to restriction endonuclease digestion with EcoRI or MspI (Boehringer Mannheim GmbH, Mannheim, Germany) according to the manufacturer's instructions. During the last 15 min of digestion $0.05 \mu \mathrm{g}$ of DNase-free RNase (Boehringer Mannheim) was added. The DNA fragments were subjected to electrophoresis in 1\% agarose gels and blotted onto Nytran nylon membranes (Schleicher \& Schuell, Dassel, Germany) as described previously (22). Hybridization was carried out as described by Sambrook et al. (22), except that the filters were soaked in $1 \%$ (vol/vol) Triton $\mathrm{X}-100$ prior to prehybridization and $0.005 \%$ sodium pyrophosphate was included in all solutions. The same filters were used for hybridization with each of the probes, and the filters were stripped between hybridization experiments by immersing them in 1 liter of boiling $0.1 \%$ SDS and then left to cool for $30 \mathrm{~min}$. The probe used for ribotyping was prepared by randomly primed reverse transcription of 16S and 23S rRNA from Escherichia coli (Boehringer Mannheim) by using murine leukemia virus reverse transcriptase (Boehringer Mannheim) $\left[\alpha{ }^{32} \mathrm{P}\right] \mathrm{dATP}$ (Amersham) was included in the reaction mixture (22). The final posthybridization wash was at $65^{\circ} \mathrm{C}$ in $0.5 \times$ SET buffer (22). Oligonucleotide probe $\mathrm{Bi} 31$, which is specific for the former $P$. intermedia genotype II ( $P$. nigrescens) (3), was end labelled by using $\left[\gamma^{32} \mathrm{P}\right] \mathrm{ATP}$ and T4 polynucleotide kinase (22). After hybridization the filters were washed five times in $6 \times$ SSC containing $0.05 \%$ sodium pyrophosphate for $3 \mathrm{~min}$ at $55^{\circ} \mathrm{C}$ and twice in the same buffer for $3 \mathrm{~min}$ at $60^{\circ} \mathrm{C}(1 \times \mathrm{SSC}$ is $0.15 \mathrm{M} \mathrm{NaCl}$ plus $0.015 \mathrm{M}$ sodium citrate $)$. In addition, whole genomic DNAs from $P$. intermedia CCUG 24042 (= ATCC 25611 ${ }^{\mathrm{T}}$ ) and $P$. nigrescens CCUG $9560\left(=\right.$ ATCC $\left.33563^{\mathrm{T}}\right)$ were labelled with $\left[\alpha{ }^{32} \mathrm{P}\right] \mathrm{dATP}$ by nick translation (22) and used as probes. A high-stringency posthybridization wash at $68^{\circ} \mathrm{C}$ in $0.1 \times$ SET buffer was used in this experiment.

SDS-PAGE of soluble cell proteins. Bacteria were grown for 2 days on dialysis membrane-coated agar plates, harvested in $0.01 \mathrm{M}$ phosphate buffer containing $0.85 \%(\mathrm{wt} / \mathrm{vol}) \mathrm{NaCl}$ and $0.05 \% \mathrm{NaN}_{3}(\mathrm{pH} 7.4$ ) by centrifugation, washed once, and then resuspended (concentration, $0.1 \mathrm{mg}$ of pellet per $\mathrm{ml}$ ). Two volumes of bacterial suspension was mixed with 1 volume of sample dissociating buffer (1.0 $\mathrm{M}$ Tris- $\mathrm{HCl}, 10 \%$ SDS, $50 \%$ sucrose, $25 \%$ mercaptoethanol, $0.25 \%$ pyronine,
$0.005 \%$ bromophenol blue [pH 8.8]), and the mixture was boiled for $5 \mathrm{~min}$. The supernatant collected after centrifugation was analyzed by electrophoresis in 4 to $20 \%$ polyacrylamide slab gradient gels (cast in the laboratory), and the gels were stained with Coomassie brilliant blue.

Detection of IgA1 degradation. Human dimeric IgA1 was isolated from the serum of a patient (Kah) with multiple myeloma as previously described (5). Bacterial colonies from agar plates were suspended in $40 \mu \mathrm{l}$ of a $1-\mathrm{mg} / \mathrm{ml}$ solution of IgA1 and tested for degradation of IgA1 after 1, 4, 24, and $48 \mathrm{~h}$ by immunoelectrophoresis. In addition, five representative strains grown to the late log phase in liquid medium, harvested, and resuspended in phosphate-buffered saline were mixed with either IgA1 at a final concentration of $1 \mathrm{mg} / \mathrm{ml}$ or buffer and incubated for $1,4,24$, and $48 \mathrm{~h}$ at $37^{\circ} \mathrm{C}$. The samples were examined by SDSPAGE and by Western blotting (immunoblotting) on polyvinylidene difluoride membranes (Immunobilon P; Millipore Corp., Bedford, Mass.) (1). The membranes were incubated with affinity-purified rabbit anti-human immunoglobulin $\alpha$ chain $(1: 2,000)$ or rabbit anti-human $\lambda$ light chain $(1: 3,000)$ (both obtained from DAKO, Glostrup, Denmark) and stained as described previously (1).

Experiments with inhibitors were carried out as previously described (6) with five representative strains grown as described above. The human physiological proteinase inhibitors $\alpha_{2}$-macroglobulin (final concentration, $0.1 \mathrm{mM}$; kindly provided by Lars Sottrup-Jensen, Institute of Molecular Biology, University of Aarhus, Aarhus, Denmark) and $\alpha_{1}$-proteinase inhibitor (final concentration, 1 $\mathrm{mM}$; Sigma) were used for preincubation and reincubation with $\operatorname{IgAl}$ for $1,4,24$, and $48 \mathrm{~h}$.

\section{RESULTS}

Genetic diversity and relationships revealed by multilocus enzyme electrophoretic typing. A total of 51 of the strains were characterized by determining the electrophoretic mobilities of 14 intracellular metabolic enzymes (detailed data are available upon request). All 14 enzymes were polymorphic, with two to seven alleles per locus (Table 1). The mean number of alleles per locus was 3.9 , and the mean level of genetic diversity per locus was 0.52 . A total of $46 \mathrm{ETs}$, each characterized by a distinct combination of electrophoretic mobilities of the 14 enzymes, were identified. Six of the ETs were represented by two strains, whereas the remaining 39 ETs contained one strain (Fig. 1). The genetic distances between ETs, which were calculated by determining the proportions of the 14 enzyme loci at which dissimilar alleles were present, were used to construct the dendrogram shown in Fig. 1. The smallest genetic distance between ETs was 0.07 , corresponding to a single difference in the 14 enzymes analyzed. The phylogenetic tree revealed two major lineages, designated divisions I and II, which separated at a mean genetic distance of 0.77 and included 21 and 30 strains, respectively (Fig. 1). The type strain of $P$. intermedia 


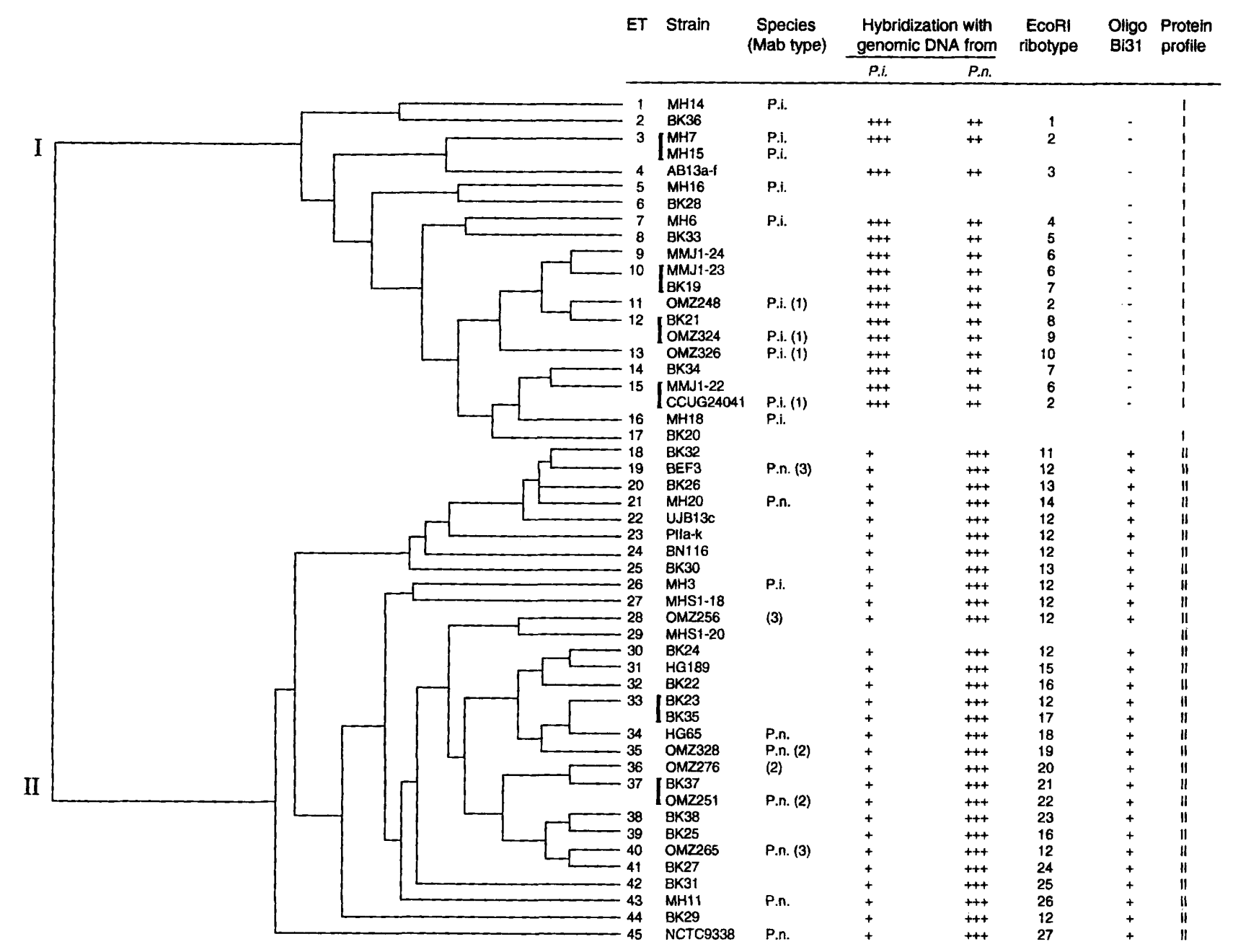

\begin{tabular}{lllllllll}
\hline 0.8 & 0.7 & 0.6 & 0.5 & 0.4 & 0.3 & 0.2 & 0.1 & 0
\end{tabular}

FIG. 1. Genetic relationships among 51 strains based on ET typing data. Two major lineages (ET divisions) that separated at a genetic distance of 0.77 are indicated on the left. The columns on the right show the ET types; strain designations; species affiliations (P.i., P. intermedia; P.n., P. nigrescens) if defined and serological reactions with monoclonal antibodies (MAb) according to Gmür and Guggenheim (8) and Gmür and Wyss (9); degrees of hybridization to MspI digests when whole genomic with monoclonal antibodies (MAb) according to Gmür and Guggenheim (8) and Gmür and Wyss (9); degrees of hybridization to $M s p 1$ digests when whole genomic
$P$. intermedia CCUG 24041 (= ATCC $\left.25611^{\mathrm{T}}\right)$ (P.i.) DNA and whole genomic $P$. nigrescens CCUG $9560\left(=\mathrm{NCTC}^{\mathrm{T}} 9336^{\mathrm{T}}=\right.$ ATCC $\left.33563^{\mathrm{T}}\right)(P . n$.) DNA were used as probes $(+,++$, and +++ indicate intensities of hybridization, as determined from Fig. 2$)$; degrees of hybridization to EcoRI digests when rRNA sequences were used as the probe or when oligonucleotide probe $\mathrm{Bi} 31$ specific for the former $P$. intermedia genotype II $(P$. nigrescens) was used; and protein profiles of soluble cellular proteins as determined by an SDS-PAGE analysis (see Fig. 4).

(CCUG 24041 [ = ATCC 25611] in ET 15) and all of the strains designated $P$. intermedia except one clustered in division $\mathrm{I}$. Strain $\mathrm{MH} 3$, which was received as $P$. intermedia, clustered with division II (ET 26) together with the type strain of $P$. nigrescens $(\mathrm{BEF} 3$ [ = NCTC $9336=$ ATCC 33563] in ET 19) and all of the strains received as $P$. nigrescens.

For every enzyme tested except glutamate dehydrogenase there was at least one allele that was shared by strains belonging to the two divisions. For glutamate dehydrogenase we observed one of two fast-migrating bands in all division I strains and one slowly migrating band in division II strains. The distances between the three bands were small, and in some strains we observed faint bands having mobilities identical to the mobility characteristic of the other species in addition to the strongly stained band.

Genetic diversity and relationships revealed by RFLP. Whole-cell DNAs were prepared from 46 of the 53 strains included in this study. Only one strain, BK22, contained visible plasmid DNA. To examine the levels of genomic similarity among strains assigned to the two divisions, Southern blots of MspI-digested whole-cell DNAs were hybridized with total genomic DNAs from the two type strains (Fig. 2). MspI was chosen for digestion because it resulted in an equal distribution of DNA fragments in the gel. A comparison of the relative intensities of the hybridizing bands divided the strains into two groups that were identical to the two divisions based on multilocus enzyme electrophoresis data (Fig. 1 and 2). As this type of hybridization is very sensitive to the amount of DNA applied to the gel, the same filter was used for hybridization with each of the two probes, and the results were based on the relative hybridization intensity. For unknown reasons, when genomic DNA from $P$. intermedia CCUG $24041\left(=\right.$ ATCC $25611^{\mathrm{T}}$ ) was used as the hybridization probe, it gave clearer results than DNA from $P$. nigrescens CCUG $9560\left(=\right.$ NCTC $9336^{\mathrm{T}}=$ 

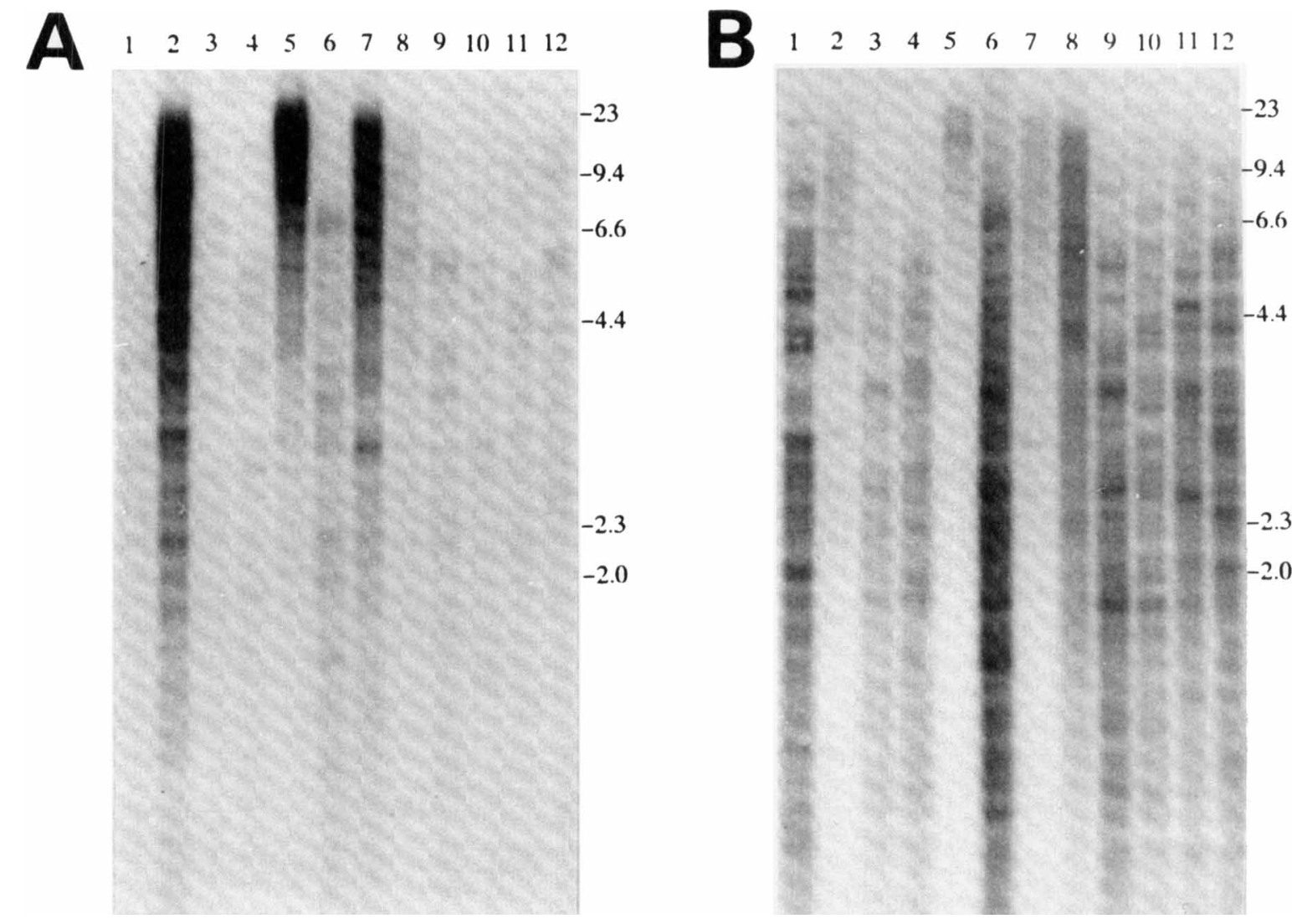

FIG. 2. RFLP analysis of chromosomal DNAs from $P$. intermedia and $P$. nigrescens strains digested with $M s p$ I and hybridized with total genomic DNA from $P$.

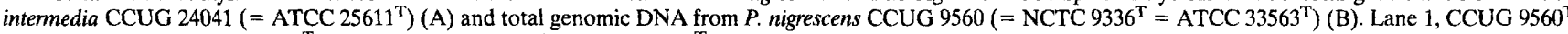
$(=$ NCTC $9336=$ ACTT 33563 $)$; lane 2, CCUG 24041 ( $=$ ATCC 25611 ${ }^{\mathrm{T}}$ ); lane 3, BK38; lane 4, BK37; lane 5, BK36; lane 6, BK35; lane 7, BK33; lane 8, BK32; lane 9, BK31; lane 10, BK30; lane 11, BK29; lane 12, BK27. The positions of size markers (in kilobases) are indicated on the right. When we took the amount of DNA applied to each lane into account and compared the intensities of hybridization in panels A and B as described in the text, lanes 2,5 , and 7 were scored +++ in panel $A$ and ++ in panel $B$. The remaining lanes were scored + in panel $A$ and +++ in panel $B$.

ATCC $33563^{\mathrm{T}}$ ) (Fig. 2). Strain MH3 reacted like $P$. nigrescens strains, which is consistent with the results of the multilocus enzyme electrophoretic analysis (Fig. 1 and 2).

To further estimate the levels of genetic diversity and relationships at the DNA level, we performed ribotyping experiments with EcoRI-digested genomic DNAs (Fig. 1 and 3A). Hybridization with the rRNA probe from $E$. coli revealed 10 different patterns among the 15 division I strains tested. A total of 17 distinct patterns were detected among the 29 division II strains tested; a single predominant type was represented by 11 strains, which were scattered throughout division II in the dendrogram based on multilocus enzyme electrophoresis data. No ribotype was shared by members of the two divisions. Both strains belonging to five of the six ETs containing two isolates were included in the ribotyping experiments. In all five ETs the two strains exhibited different ribotypes, indicating that they represent different clones.

Oligonucleotide probe $\mathrm{Bi} 31$, which originated from the rRNA genes and was previously found to be specific for the former $P$. intermedia genotype II ( $P$. nigrescens), hybridized to all division II strains, including strain MH3 (Fig. 1 and 3), whereas no hybridization to the division I strains was observed.

Protein profiles. SDS-PAGE of soluble cellular proteins of all of the strains included in this study except strain MH18, which was lost and could not be replaced, resulted in overall very similar patterns for the strains belonging to the two species (Fig. 4). However, the location of a single predominant band with a molecular weight of approximately 20,000 consistently separated the strains, which was consistent with the results obtained with the other methods (Fig. 1 and 4).

Degradation of IgA1. After $24 \mathrm{~h}$ of incubation with IgA1 each strain produced immunoelectrophoretic patterns for IgA1 degradation products identical to those described previously (10): two precipitation lines (Fig. 5, experiments B1 and C1) previously identified as $\mathrm{Fab}$ and $\mathrm{Fc}$ fragments (10); one precipitation line with an electrophoretic mobility significantly different from that of intact IgA1 (Fig. 5, experiments B4 and C4) and previously identified as an Fc fragment; or no precipitation lines, which was interpreted as total degradation of the IgA1 substrate (Fig. 5, experiments B24 and C24). After prolonged incubation for $48 \mathrm{~h}$ with a heavy inoculum of bacteria, all strains completely degraded IgA1, as revealed by the total absence of precipitation lines (Fig. 5).

To examine the kinetics of IgA1 degradation, aliquots of IgA1 and buffer were incubated with equal amounts of five representative strains grown in liquid culture to the late log phase. Each reaction mixture was subsequently reduced and subjected to SDS-PAGE and Western blot analyses (Fig. 6). Overall similar patterns of $\alpha$ heavy chain degradation were observed for all five strains tested. After $1 \mathrm{~h}$, intense staining with antibodies against the $\alpha$ chain occurred, with bands corresponding to the intact monomeric $\alpha$ chain (apparent molecular weight, 61,000), a fragment with an apparent molecular weight of 46,500 , and a fragment with an apparent molecular 

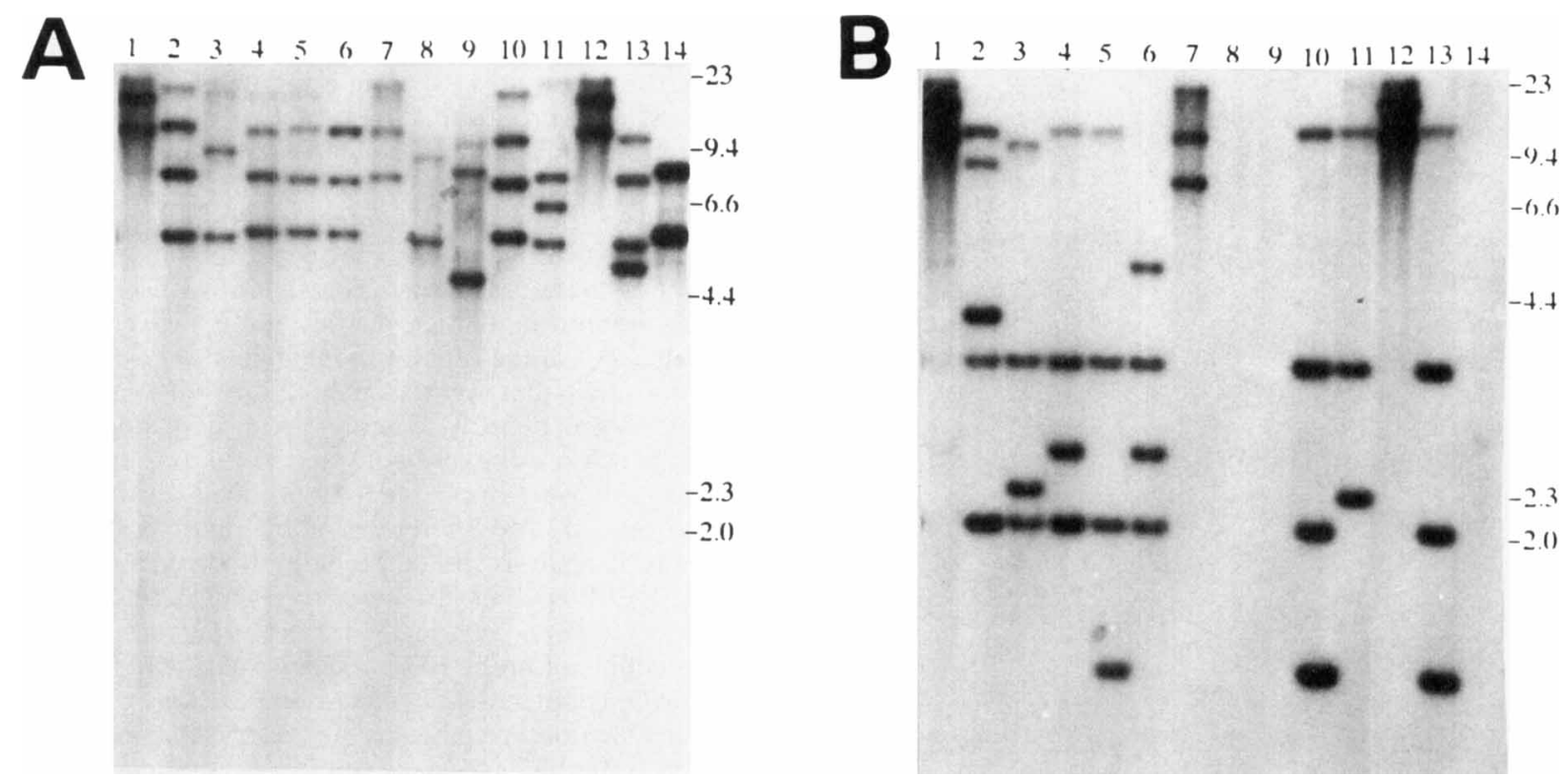

FIG. 3. RFLP analysis of chromosomal DNAs from $P$. intermedia and $P$. nigrescens strains digested with $E$ coRI and hybridized with an rRNA probe from $E$. coli (A) and oligonucleotide probe Bi31 specific for the former $P$. intermedia genotype II $(P$. nigrescens $)$ (B). Lane 1 HG65; lane 2, CCUG $9560\left(=\right.$ NCTC $9336^{\mathrm{T}}=$ ATCC 33563 ); lane 3, NCTC 9338; lane 4, OMZ265; lane 5, OMZ256; lane 6, MH20; lane 7, MH11; lane 8, MH7; lane 9, MH6; lane 10, MH3; lane 11, OMZ328; lane 12, OMZ310; lane 13, OMZ251; lane 14, CCUG $24041\left(=\right.$ ATCC $\left.25611^{\mathrm{T}}\right)$. The positions of size markers (in kilobases) are indicated on the right.

weight of 35,500. Only a faint band with an apparent molecular weight of 35,500 was observed after incubation for $48 \mathrm{~h}$ (Fig. $6 \mathrm{~A})$. The $46.5-\mathrm{kDa}$ fragment may reflect proteolytic degradation of a single domain, while the $35.5-\mathrm{kDa}$ fragment may reflect proteolytic degradation of two domains. The $\lambda$ light chain of the substrate IgA1 (apparent molecular weight, 30,000 ) was also degraded, and a breakdown product with an apparent molecular weight of 14,000 was observed; this product was also degraded after incubation for $48 \mathrm{~h}$ (Fig. 6B).

To examine if all or part of the proteolytic activity was

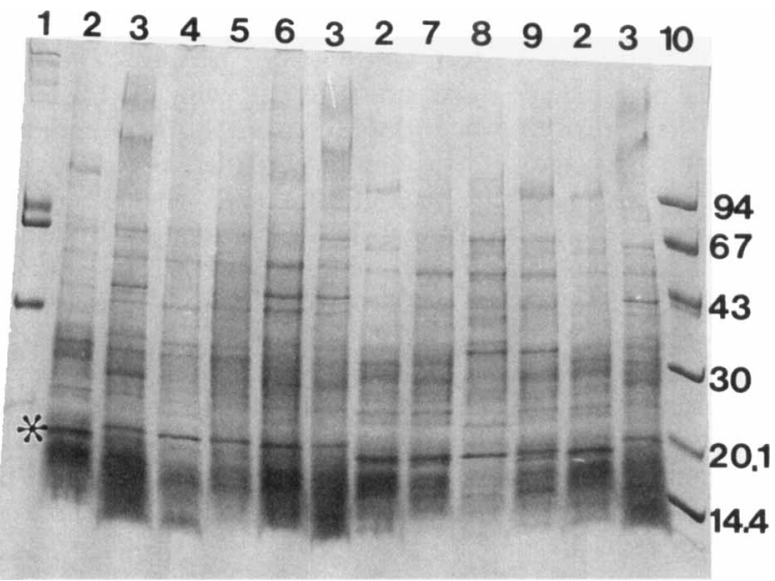

FIG. 4. SDS-PAGE of soluble cellular proteins from reference strains of $P$. intermedia and $P$. nigrescens and wild strains that clustered with one of the two species. Lanes 1 and 10, high-molecular-weight and low-molecular-weight standards (Bio-Rad Laboratories, Richmond, Calif.), respectively; lane 2, P. nigrescens CCUG $9560\left(=\right.$ NCTC $9336^{\mathrm{T}}=$ ATCC $\left.33563^{\mathrm{T}}\right)$; lane $3, P$. intermedia CCUG 24041 (=ATCC $25611^{\mathrm{T}}$ ); lane 4, BK36; lane 5, BK28; lane 6, P. intermedia OMZ324; lane 7, HG189; lane 8, MHS1-20; lane 9, MH3. The band that differentiates species is indicated by an asterisk. Protein profile $I$ is represented by the $P$. intermedia strains in lanes 3 through 6 . Protein profile II is represented by the $P$. nigrescens strains in lanes 2 and 7 through 9 . influenced by protease inhibitors, five representative strains were tested for their ability to degrade IgA1 after preincubation with the human physiological proteinase inhibitors $\alpha_{2}$ macroglobulin and $\alpha_{1}$-proteinase inhibitor. This experiment revealed that the degradation of $\operatorname{IgA} 1$ was not influenced by these protease inhibitors (e.g., Fig. 5).

\section{DISCUSSION}

A total of 53 strains, including the type strains of $P$. intermedia and $P$. nigrescens, as well as reference collection strains and fresh dental plaque isolates, were subjected to various tests

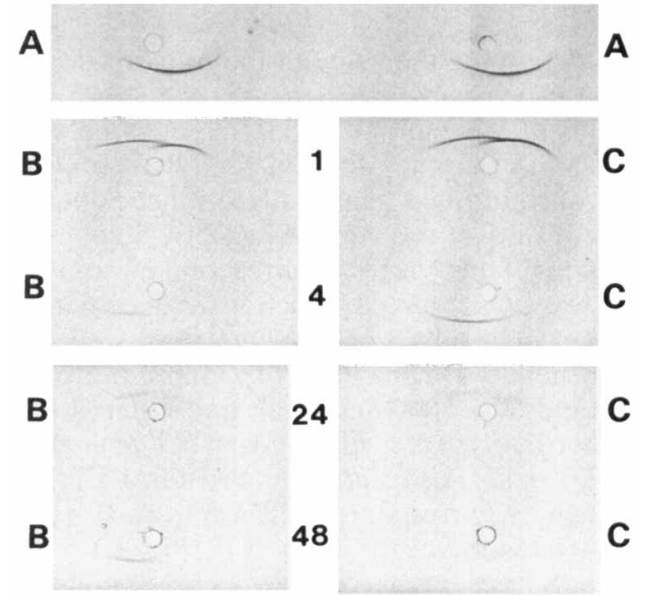

FIG. 5. Immunoelectrophoretic patterns of $\operatorname{IgAl}$ after incubation with buffer (A), $P$. nigrescens CCUG $9560\left(=\right.$ NCTC $9336^{\mathrm{T}}=$ ATCC $\left.33563^{\mathrm{T}}\right)$ cells preincubated for $1.5 \mathrm{~h}$ with buffer (B), and $P$. nigrescens CCUG 9560 (= NCTC $9336^{\mathrm{T}}$ $=$ ATCC $33563^{\mathrm{T}}$ ) cells preincubated with $\alpha_{2}$-macroglobulin at a final concentration of $1 \mathrm{mM}(\mathrm{C})$. Preparations were incubated at $37^{\circ} \mathrm{C}$ for $1,4,24$, and $48 \mathrm{~h}$, as shown on the figure. 

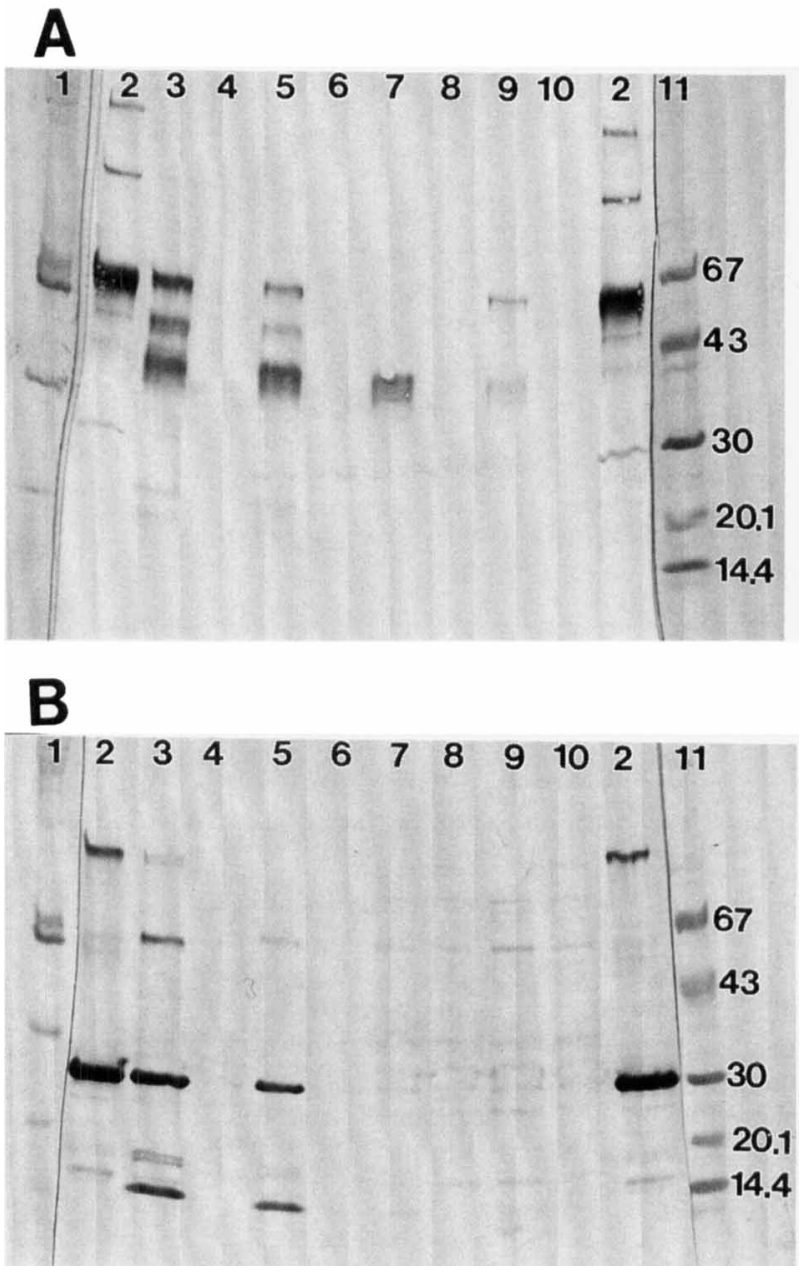

FIG. 6. Western blots of reduced SDS-PAGE gels containing IgA1 after digestion by $P$. nigrescens HG189 stained with anti- $\alpha$ chain (A) and anti- $\lambda$ light chain (B). The bacteria and substrate were incubated for $1 \mathrm{~h}$ (lane 3), $4 \mathrm{~h}$ (lane 5), $24 \mathrm{~h}$ (lane 7), and $48 \mathrm{~h}$ (lane 9). Bacteria were also incubated in buffer as controls for $1 \mathrm{~h}$ (lane 4$), 4 \mathrm{~h}$ (lane 6), $24 \mathrm{~h}$ (lane 8), and $48 \mathrm{~h}$ (lane 10). Lane 2 contained IgA1 incubated with buffer. Lanes 1 and 11 contained molecular weight standards.

in order to determine the value of the tests for discriminating between the two species.

The results of our multilocus enzyme electrophoretic analysis based on 14 enzymes showed that $P$. intermedia and $P$. nigrescens constitute two genetically distinct populations and support the results of a quantitative DNA homology analysis (24). Additional heterogeneity corresponding to a third serotype $(8,9)$ was not observed, which is in agreement with previously reported results $(4,24)$. Our results confirmed the combined results of Devine et al. (4), Gmür and Guggenheim (8), Gmür and Wyss (9), and Shah and Gharbia (24) which indicated that serotype 1 corresponds to $P$. intermedia (formerly genotype I of $P$. intermedia; our division I [Fig. 1]), while serotypes 2 and 3 correspond to $P$. nigrescens (formerly genotype II of $P$. intermedia; our division II [Fig. 1]).

It has been suggested that differences in the mobilities of the enzymes malate dehydrogenase and glutamate dehydrogenase can be used as differentiating characteristics for the two species (24). In this study, malate dehydrogenase was detected in seven alleles, some of which were shared by strains of both species. Glutamate dehydrogenase was detected in only three alleles, in overall agreement with the two different mobilities reported previously (24). Thus, the $P$. nigrescens strains used in our study produced only one slowly migrating band, while the $P$. intermedia strains produced either of two fast-migrating bands. However, some strains produced faint bands with mobilities identical to the mobility of the band in the other species in addition to the strongly stained band. In addition, a single mutation may influence the electrophoretic mobility of an enzyme. For these reasons, species differentiation based on the electrophoretic mobilities of only these two enzymes is not advisable. All of the other enzymes which we examined had at least one allele that occurred in both divisions, and many of the enzymes were difficult to score because of double or triple bands, which presumably were due to the presence of conformational isozymes or degradation products (20). Thus, we concluded that species differentiation by multilocus enzyme electrophoretic analysis should be based on several enzymes.

The RFLP analysis also confirmed that $P$. intermedia and $P$. nigrescens are two genetically distinct populations. In addition, the reliability of probe $\mathrm{Bi} 31$, which is specific for the former $P$. intermedia genotype II ( $P$. nigrescens) (3), was confirmed. The very diverse ribotype patterns of $P$. intermedia and $P$. nigrescens make this method especially suitable for epidemiological studies.

In this study we found that the location of a single predominant band in SDS-PAGE gels containing soluble cellular proteins provided a way to reproducibly differentiate the two species. The protein profiles of five strains representing the two genotypes of the former species $P$. intermedia were presented by Johnson and Holdeman (12), but the usefulness of these profiles for discrimination was not commented upon. Gharbia et al. reported that a $31-\mathrm{kDa}$ band was present in $P$. nigrescens but absent in $P$. intermedia (7). However, inspection of the illustration of these authors revealed a band with a molecular weight of approximately 29,000 in $P$. intermedia. Since the electrophoretic conditions which Gharbia et al. used differed from our conditions, we cannot eliminate the possibility that we observed the same phenomenon.

All of the strains of both species were capable of totally degrading human IgA1. Thus, the different degradation patterns observed previously (14) were presumably due to variations in the amounts and conditions of the bacteria in the reaction mixtures. Western blotting (Fig. 6) showed the presence of a $35.5-\mathrm{kDa}$ degradation fragment, which on the basis of its size has previously been identified as the Fc fragment of IgA1 after cleavage with specific IgA1 proteases $(6,19)$. However, it is not clear on the basis of our results whether a specific IgA1 protease was involved in IgA1 degradation by the two Prevotella species, since Fab fragments with molecular weights of approximately 26,000 were not observed. The inability of physiological human proteinase inhibitors to prevent part or all of the proteolytic degradation of IgA1 could be due to the resistance of the IgA1-degrading enzymes to the protease inhibitors or to degradation of the inhibitors (2). Since the IgA1degrading enzymes were not influenced by physiological protease inhibitors, they might be expected to be active in vivo in periodontal pockets.

In conclusion, in this study we confirmed that $P$. intermedia and $P$. nigrescens represent genetically distinct populations of bacteria. The methods which we employed allow clear separation of the two species.

\section{ACKNOWLEDGMENTS}

We especially thank Bodil Damgaard for excellent technical assistance. 
This study was supported by Aarhus University Research Foundation grant E-1993-SUN-1-145 and by the Danish Medical Research Council.

\section{REFERENCES}

1. Ahl, T., and J. Reinholdt. 1991. Detection of immunoglobulin A1 proteaseinduced $\mathrm{Fab}_{\mathrm{\alpha}}$ fragments on dental plaque bacteria. Infect. Immun. 59:563569.

2. Carisson, J., B. F. Herrmann, J. F. Höfling, and G. K. Sundqvist. 1984 Degradation of the human proteinase inhibitors alpha-1-antitrypsin and alpha-2-macroglobulin by Bacteroides gingivalis. Infect. Immun. 43:644-648.

3. Chuba, P. J., K. Pelz, G. Krekeler, T. S. de Isele, and U. Göbel. 1988 Synthetic oligodeoxynucleotide probes for the rapid detection of bacteria associated with human periodontitis. J. Gen. Microbiol. 134:1931-1938.

4. Devine, D. A., M. A. Pearce, S. E. Gharbia, H. N. Shah, R. A. Dixon, and R. Gmür. 1994. Species-specificity of monoclonal antibodies recognizing Pre votella intermedia and Prevotella nigrescens. FEMS Microbiol. Lett. 120:99104

5. Frandsen, E. V. G. 1994. Carbohydrate depletion of immunoglobulin A1 by oral species of gram-positive rods. Oral Microbiol. Immunol. 9:352-358.

6. Frandsen, E. V. G., J. Reinholdt, and M. Kilian. 1987. Enzymatic and antigenic characterization of immunoglobulin A1 proteases from Bacteroides and Capnocytophaga spp. Infect. Immun. 55:631-638.

7. Gharbia, S. E., M. Haapasalo, H. N. Shah, A. Kotiranta, K. Lounatmaa, M. C. Pearce, and D. A. Devine. 1994. Characterization of Prevotella intermedia and Prevotella nigrescens isolates from periodontic and endodontic infections. J. Periodontol. 65:56-61.

8. Gmür, G., and B. Guggenheim. 1983. Antigenic heterogeneity of Bacteroides intermedius as recognized by monoclonal antibodies. Infect. Immun. 42:459470.

9. Gmür, R., and C. Wyss. 1985. Monoclonal antibodies to characterize the antigenic heterogeneity of Bacteroides intermedius, p. 91-119. In A. J. L. Macario and E. Conway de Macario (ed.), Monoclonal antibodies against bacteria, vol. 1. Academic Press, New York.

10. Haffajee, A. D., and S. S. Socransky. 1994. Microbial etiological agents of destructive periodontal diseases. Periodontology 2000 5:78-111.

11. Jensen, S. B., H. Löe, C. R. Schiött, and E. Theilade. 1968. Experimental gingivitis in man. IV. Vancomycin induced changes in bacterial plaque composition as related to development of gingival inflammation. J. Periodontal Res. 3:284-293.

12. Johnson, J. L., and L. V. Holdeman. 1983. Bacteroides intermedius comb. nov. and descriptions of Bacteroides corporis sp. nov. and Bacteroides levii sp. nov. Int. J. Syst. Bacteriol. 33:15-25.

13. Kilian, M. 1978. Rapid identification of Actinomycetaceae and related bacteria. J. Clin. Microbiol. 8:127-133.

14. Kilian, M. 1981. Degradation of immunoglobulins A1, A2, and G by suspected principal periodontal pathogens. Infect. Immun. 34:757-765.

15. Kilian, M. 1991. Haemophilus, p. 463-470. In A. Balows, W. J. Hausler, Jr K. L. Herrmann, H. D. Isenberg, and H. J. Shadomy (ed.), Manual of clinical microbiology, 5th ed. American Society for Microbiology, Washington, D.C

16. Laughon, B. E. S. A. Syed, and W. J. Loesche 1982 API ZYM system for identification of Bacteroides spp., Capnocytophaga spp., and spirochetes of oral origin. J. Clin. Microbiol. 15:97-102.

17. Laughon, B. E., S. A. Syed, and W. J. Loesche. 1982. Rapid identification of Bacteroides gingivalis. J. Clin. Microbiol. 15:345-346.

18. Moore, W. E. C., and L. V. H. Moore. 1994. The bacteria of periodontal diseases. Periodontology 2000 5:66-77.

19. Mortensen, S. B., and M. Kilian. 1984. Purification and characterization of an immunoglobulin A1 protease from Bacteroides melaninogenicus. Infect. Immun. 45:550-557.

20. Murphy, R. W., J. W. Sites, Jr., D. G. Buth, and G. H. Haufier. 1990. Proteins 1: isozyme electrophoresis, p. 45-126. In D. M. Hillis and C. Moritz (ed.) Molecular systematics. Sinauer Associates, Inc., Sunderland, Mass.

21. Poulsen, K., P. Hjorth, and M. Kilian. 1988. Limited diversity of the immunoglobulin A1 protease gene (iga) among Haemophilus influenzae serotype b strains. Infect. Immun. 56:987-992.

22. Sambrook, J., E. F. Fritsch, and T. Maniatis. 1989. Molecular cloning: a laboratory manual, 2nd ed. Cold Spring Harbor Laboratory, Cold Spring Harbor, N.Y.

23. Selander, R. K., D. A. Caugant, H. Ochman, J. M. Musser, M. N. Gilmour, and T. S. Whittam. 1968. Methods of multilocus enzyme electrophoresis for bacterial population genetics and systematics. Appl. Environ. Microbiol. 51:873-884.

24. Shah, H. N., and S. E. Gharbia. 1992. Biochemical and chemical studies on strains designated Prevotella intermedia and proposal of a new pigmented species, Prevotella nigrescens sp. nov. Int. J. Syst. Bacteriol. 42:542-546.

25. Slots, J., and H. S. Reynolds. 1982. Long-wave UV light fluorescence for identification of black-pigmented Bacteroides spp. J. Clin. Microbiol. 16: 1148-1151.

26. van Winkelhoff, A. J., T. J. M. van Steenbergen, and J. de Graaff. 1988. The role of black-pigmented Bacteroides in human oral infections. J. Clin. Periodontol. 15:145-155. 